\title{
Bir Arada Yaşama Bağlamında Hz. Ömer Döneminde Kudüs
}

Rabia MERT*

Jerusalem in the Omar Period in the Context of Coexistence

Citation/@): Mert, Rabia, (2019). Jerusalem in the Omar Period in the Context of Coexistence, Milel ve Nihal, 16 (1), 199-215.

Abstract: Jerusalem is considered sacred by Jews and Christians as well as Muslims. In addition, people who believe in the sanctity of the city give importance to living there. Thus, the most controversial area on Jerusalem is the coexistence of members of different religions. In this article, the Omar period was evaluated in the context of the practices of living together with Jews and Christians. It is accepted that Muslims have built a society based on coexistence since the early days of Islam. Although some political decisions have been taken during the caliph Omar period, it can be said that this approach has been followed in accordance with this understanding and it is an example for later periods.

Keywords: Jerusalem, Caliph Omar, Coexistence, The Aman, Dhimmi.

Atıf/C: Mert, Rabia, (2019). Bir Arada Yaşama Bağlamında Hz. Ömer Döneminde Kudüs, Milel ve Nihal, 16 (1), 199-215.

Öz: Kudüs, Müslümanlar yanında Yahudi ve Hıristiyanlar tarafından da kutsal kabul edilmektedir. Ayrıca şehrin kutsalığına inanan kimseler orada yaşamaya önem vermektedir. Böylece Kudüs konusunda en fazla tartışmalı alanı farklı dinlerin mensuplarının bir arada yaşaması oluşturmaktadır. Bu makalede Hz. Ömer dönemi Kudüs'ü, Yahudi ve Hıristiyanlarla bir arada yaşama konusundaki uygulamalar bağlamında değerlendirilmiştir. Müslümanların İslam'ın ilk dönemlerinden itibaren bir arada yaşamaya dayalı

* Dr. Öğr. Üyesi, Sinop Üniversitesi İlahiyat Fakültesi, Din Bilimleri Anabilim Dalı, [rabia_mert_26@hotmail.com]. 
bir toplum inşa ettikleri kabul edilmektedir. Halife Ömer döneminde birtakım siyasi kararlar alınmakla birlikte bu anlayışa uygun hareket edildiği ve daha sonraki dönemler için de örneklik teşkil ettiği söylenebilir. Anahtar Kelimeler: Kudüs, Hz. Ömer, Bir Arada Yaşama, Eman, Zimmi.

\section{Giriş}

Günümüzde, gittikçe artan iletişim ve seyahat imkânları nedeniyle dünyanın hemen her tarafında rastlanan çok kültürlülüğün sonucu olarak farklı etnik, dini ve kültürel kimliklere sahip insanların ortak bir mekânı paylaşarak bir arada yaşama tecrübesi artmıştır. Bu makalede -bugün yaşananların biraz da geçmişte yaşananların etkisiyle oluştuğundan hareketle- Yahudi, Hıristiyan ve Müslümanlar için önemli bir şehir olan Kudüs'ün Hz. Ömer tarafından M 638 y1lındaki fethi ve sonrasındaki hadiseler, bir arada yaşamanın imkânı bağlamında incelenmiştir.

Bu bağlamda farklılıkları ortadan kaldırmadan bir arada yaşamanın imkânı nedir, farklılıklara müsaade etmenin sınırı nasıl belirlenebilir, farklılıklar çatışma-ayrışma vesilesi olarak mı yoksa kültürel zenginlik kaynağı olarak mı görülmelidir, sorularının cevaplanması önemlidir. Konunun anlaşılması amacıyla öncelikle müşterek mekânda yer alan dinlerin müntesiplerinin öteki insanlara karşı hangi tutum ve davranışlar içinde olduklarına bakılmalıdır. Burada dinlerin ötekine karşı genel olarak kapsayıcı ve dışlayıcı olarak adlandırılan görüşleri benimsedikleri görülmektedir. Dışlayıc1lar, her dinin kendi hakikat iddiasının tek doğru olduğuna inanır. Buna göre dışlayıcılık, hakikatin yalnızca tek bir dinde ve kurtuluşun da sadece bu hakikati içeren dinde var olduğu anlayışıdır. Bu açıdan bakıldığında dışlayıcılık, hoşgörüsüzlük gibi anlaşılmaktadır. Lakin bu görüşteki insanlar, inanç farklılıklarının suç olmadığını aynı zamanda bu farklılıkların görmezden gelinmemesi gerektiğini de söylemektedirler. Böylece dişlayıcılığa göre inanç esaslarındaki farklılıklar üzerindeki tartışmalar bir sonuca varamayacaktır. Buna karşılık dışlayıcılığın, toleranssızlık yerine her dinin kendi biricikliğini devam ettirmek istemesi olarak anlaşılması daha uygun olacaktır. ${ }^{1}$ Kapsayıcılıkta ise bir din doğru kabul edilip ina-

1 Mustafa Köylü, “Dinsel Dışlayıcılık”, İslam ve Öteki, ed.: Cafer Sadık Yaran, (İstanbul: Kaknüs Yayınları, 2001), ss. 34, 59. 
nılırken diğer dinlerde de o dinin bazı yönlerinin bulunduğu savunulmaktadır. Buna göre bir dinin üstünlüğü kabul edilirken öteki dinlere de göreceli bir yer verilmektedir; ancak bu husus inanılan dinin diğer dinlerle eşit ve aynı derecede kabul edilmesi şeklinde anlaşılmamalıdır. ${ }^{2} \mathrm{Bu}$ açıklamalardan sonra bir arada yaşamanın imkânı için ilk önce yapılacak işin dinler arasındaki farklılıkları ortadan kaldırmak/yok saymak yerine dinlerin ayırt edici özelliklerinin bilincinde olarak birlikte yaşamayı öğrenmek olduğu ifade edilmelidir. Bu konuda Müslümanların tutumuna bakıldığında ise Kur'an'a ve Hz. Peygambere inanıp tek doğru dinin İslam olduğuna inanmakla beraber Yahudi ve Hiristiyanlarla farklılıklarının da bilincinde oldukları; fakat bu farklılıkları kendilerine bir tehdit kabul etmedikleri görülecektir.

\section{I.}

Öncelikle şunu belirtmek gerekir ki İslam dininde, insanlar arasındaki farklılıkların ilahi bir kanun olduğu belirtilmekte ${ }^{3}$ aynı zamanda farklılıklara saygı ve hoşgörü emredilmektedir. ${ }^{4}$ Buna uygun şekilde Müslümanlar farklı dinlere mensup insanları zimmi adı verilen özel bir statüde topluma dâhil etmişlerdir. Böylece Müslüman olanlar ile gayri Müslimlerin bir arada yaşaması hedeflenmiştir. Müslümanlar 7. yüzyılda Orta Doğu'yu tamamen ele geçirdiklerinde bölgedeki Hıristiyan topluluklarla birlikte yaşamaya dayalı yeni bir anlayışı yerleştirmişlerdir. Bahsedilen anlayışta İslam’ın ortaya çıktığı ilk dönemdeki Müslümanların Yahudi ve Hıristiyanlarla bir arada yaşamaya dayanan tecrübelerinin önemli bir yeri bulunduğu da belirtilmelidir. Şöyle ki Hz. Peygamber dönemi İslam toplumunda, Yahudi veya Hıristiyan kimselerin Müslümanlarla birlikte yaşamasına imkân sağlanmış, dinlerini yaşama özgürlükleri tanınmış ve bu güvence altına alınmıştır. Burada şunu da söylemeliyiz ki Hz. Ömer'in Yahudi ve Hiristiyanlarla bir arada yaşamaya yönelik uygulamalarında Hz. Peygamber döneminin örnekliği çok açık şekilde görülmektedir. Nitekim Hz. Peygamber döneminde Medine toplumu içinde yer almayan Necran Hıristiyanları ile yapılan anlaşmayla can, mal, din ve kiliseleri hak-

2 Cafer Sadık Yaran, “Dinsel Kapsayıcılık”, İslam ve Öteki, ed.: Cafer Sadık Yaran, (İstanbul: Kaknüs Yayınları, 2001), s. 67, 68, 71.

3 Hud 12/118; Nahl 16/93; Şura 42/8; Maide 5/48.

4 Maide 5/8; Mümtehine 60/8. 
kında tanınan haklar daha sonra verilen emanlarla devam ettirilmiştir. Aynı şekilde Hz. Peygamber döneminde Yahudilerle olan ilişkiler de bir arada yaşama bakımından Hz. Ömer'in hilafetinde örneklik teşkil etmiştir. Böylece İslam toplumunda insanlar inanç açısından gruplara ayrılmakla birlikte bir arada yaşama için gerekli düzenlemelerin ilk zamanlardan itibaren yapıldığı, sonraki süreçte de detaylandırıldığı anlaşılmaktadır.

Bununla birlikte Yahudi ve Hıristiyanlar tarafından değer verilen Kudüs'ün Hz. Ömer döneminde fethedildiğinde burada nasıl bir tutum izlendiğinin bilinmesi önem arz etmektedir. Ayrıca bu dönem Müslüman yönetimlerinin burada hâkim olduğu asırlar boyunca bir arada yaşama için model oluşturması bakımından da önemlidir. Diğer yandan Hz. Ömer' in hilafetinde -yapılan fetihlerle sınırların genişlemesi ve İslam toplumunun bir devlet olarak en fazla kurumlaştığı dönem olması itibariyle- birtakım yeni ve farklı uygulamalar da gerçekleşmiştir. Bahsedilen hususlara ve çeşitli tartışmalara Hz. Ömer dönemi Kudüs'ü çerçevesinde aşağıdaki kısımlarda yer verilecektir.

Öte taraftan günümüzde binlerce yıllık geçmişe sahip kadim şehir Kudüs üzerindeki en fazla tartışmanın bir arada yaşama konusunda olması dikkat çekmektedir. Kuşkusuz şehir Yahudi ve H1ristiyanlar için olduğu gibi Müslümanlar için de önemlidir. Dolayısıyla şehrin Müslümanların egemenliğine ilk geçtiğinde neler yaşandığı daha önemli hale gelmektedir. Bunun yanında adaleti ile tanınmış Hz. Ömer'in fethinden sonra Yahudi ve Hıristiyanların şehirde yaşamalarına imkân tanıyan, aynı zamanda diğer din mensuplarının hak ve sorumlulukların içeren eman belgesinden de söz edilmelidir. Bahsedilen eman belgesinde farklı dinlere mensup insanlara sağlanan güvenlik teminatı yanında barış, birlikte yaşama ve karşlıklı saygı gibi hususlar da görülmektedir. Bu belge Müslümanların gayri Müslimlerle bir arada yaşamasına izin verirken İslam'ın diğer dinlere karşı hoşgörüsüne de işaret etmektedir. Böylelikle farklı dinlerden insanların çatışma olmadan bir arada yaşamasına imkân tanındığı söylenebilmektedir.

II.

Müslümanlar, Hz. Ebubekir döneminde Suriye-Filistin bölgesinde fetih hareketlerine başlamış bulunuyorlardı. Lakin Suriye bölgesinin kaderi Hz. Ömer döneminde Yermük'te Bizans kuvvetlerine karşı yapılan savaşın kazanılması ile değişmiştir. Müslümanların 
bölgedeki hareketleri devam ettiği sırada Bizans imparatoru Herakliyus, Suriye bölgesinde bulunmaktadır. Herakliyus, gerçekleştirdiği askeri faaliyetler neticesinde İranlıları mağlup etmiş ve gerçek olduğuna inanılan haçı onlardan geri almıştır. Daha sonra ise gerçek haçı yerleştirmek üzere Kudüs'e gitmiştir. Bu esnada kardeşi Theodorus komutasında bir birliği de Müslümanların üzerine göndermiştir. Theodorus'un komutasındaki Bizans ordusunun mağlup olması üzerine imparator, Suriye bölgesinden ayrılarak Konstantin'e gitmiştir. Herakliyus'un ayrılırken hüzünlenerek Ey Suriye! Sana selam olsun, burası düşman için ne güzel bir ülke olacaktır, dediği ifade edilmektedir. ${ }^{5}$ Kaynaklarda yer alan bilgilere göre Hıms bölgesinde bulunan Müslümanlar, Yermük savaşı için Herakliyus'un hazırlık yaptığını öğrendiklerinde buranın halkından alınan cizyeyi, savaş nedeniyle kendilerini koruyamayacaklarını söyleyerek iade etmişlerdir. Müslümanların bu adaletli davranışı Yahudi ve $\mathrm{H}_{1}-$ ristiyan halklar tarafından takdirle karşılanmıştır. Ayrıca Müslümanların bu tutumu bölgedeki farklı dinlerden insanların Bizans karşısında onları desteklemesinde etkili olmuştur. ${ }^{6}$

Suriye bölgesindeki diğer yerlerin fethedilmesinden sonra $\mathrm{Hz}$. Ömer, Amr bin As'a bir mektup göndererek İlya/Kudüs'ü kuşatmasını istemiştir. Bunun üzerine harekete geçen bölgenin genel komutanı Ebu Ubeyde, İlya halkına mektup yazarak İslam'a davet etmiş, aksi takdirde cizye vermelerini istemiş bunları kabul etmemeleri halinde savaş açılacağını bildirmiştir. İlya halkı, önce teklifleri reddetmiş; lakin daha sonra Şam diyarındaki diğer yerlerin halklarıla yapılan anlaşma ile benzer şartlarda bir anlaşma yapmaya razı olmuştur. Ancak anlaşmayı bizzat Halife Ömer ile yapmak istemişlerdir. Bunun üzerine Hz. Ömer, Kudüs'e doğru yola çıkmıştır.7 Kaynaklarda bu şartın sebebi açık değilse de Kudüs'ün kutsal bir şehir kabul edilmesi dolayısıyla olduğunu düşündürmektedir. Zira halifenin şehri ziyaretinde yaşananlar da buna işaret etmektedir. Halife, Şam bölgesindeki Cabiye'ye gelirken yolda cüzzam hastalığı

5 Belâzurî, Fütûhu'l-Büldân, çev.: Mustafa Fayda, (Ankara: Kültür ve Turizm Bakanlığ1 Yayınları, 1987), s. 195; Philip Khuri Hitti, Siyasal ve Kültürel İslam Tarihi, çev.: Salih Tuğ, (İstanbul: İFAV, 2011), s. 209, 211, 216.

6 Belâzurî, Fütûhu'l-Büldân, ss. 195-196.

7 Belâzurî, Fütûhu'l-Büldân, s. 197; İbn Kesîr Ebü'l-Fidâ İmâdüddin İsmâil b. Şihâbiddîn Ömer; el-Bidaye ve'n-Nihaye, (Amman: Beytü'l Efkarü'l Devliyye, 2004), c. 1, s. 1243. 
olan Hıristiyanlarla karşılaşmıştır. Bunun üzerine görevlilerden yiyecek getirmelerini istemiş ve onlara zekât gelirlerinden verilmesini emretmiştir. ${ }^{8}$ Daha sonra Cabiye'ye gelen halifeyi orada Ebu Ubeyde, Halid bin Velid ve Yezid bin Ebu Süfyan karşılamıştır. Hz. Ömer orada iken İlya halkından bir grup kimsenin geldiği görülmüş ve onlarla burada anlaşma yapılmıştır. Şehrin komutanı Artaban, daha önce Mısır bölgesine kaçtığı için barış görüşmelerini Kudüs patriği Sophronius yürütmüştür. ${ }^{9}$

Şehrin ele geçirilmesi üzerine Hz. Ömer'in İlya/Kudüs halkına verdiği eman/ahidnamenin maddeleri şu şekildedir ${ }^{10}$ :

- İlya halkının insanlarına, kiliselerine ve haçlarına eman verilmiştir. Bu eman şehirde yaşayanları, tarlalarda bulunanları, hastaları ve sağlamları kapsamaktadır.

- Müslümanlar onların kiliselerinde iskân etmeyecek, kiliseleri ve haçları yıkılmayacak, en küçük bir parçası bile azaltılmayacak, dinlerinden vazgeçmeye zorlanmayacaklar

- Yahudilerin İlya'da onlarla birlikte yaşamasına müsaade edilmeyecek

- İlya halkı Bizanslıları ve hırsızları şehirde barındırmayacak

- Bizanslılarla birlikte şehirden ayrılacak olanların gidecekleri yere kadar hem kendileri hem malları güvende olacak

- İlya'da oturmak isteyenler cizye ödeyerek şehirde kalabilirler

Bu eman ile Kudüs'te üç din mensuplarının bir arada yaşamasına imkân tanınıp tanınmadığını söylemek için önce bazı sorular sormak gerekmektedir. Ahitnamedeki bazı maddeler Hz. Ömer'in meşhur adalet temelli yönetim anlayışı ile çelişmekte midir ve eman Hıristiyanlara yönelik çeşitli baskılar içermekte midir? Öncelikle şunu belirtmeliyiz ki Hz. Ömer, İslam'ın genel anlayışına uygun olarak Hıristiyan halkın din özgürlüğünü gerekli görmektedir. Bu nedenle kiliselerin varlığına dokunmamış ve dinlerini yaşamalarına müdahale etmemiştir. Zaten ahidnamede yer alan maddeler de

8 Belâzurî, Fütûhu'l-Büldân, s. 185.

9 İbn Kesîr, el-Bidaye ve'n-Nihaye, c. 1, s. 1244; İbnü'l Esîr; el-Kamil Fi't Tarih Tercümesi İslâm Tarihi, çev.: M. Beşir Eryarsoy, (İstanbul: Bahar Yayınları, 1985), c. 2, ss. $459-460$.

10 Moudjir ed-Dyn, Histoire De Jerusalem Et D'Hebron Depuis Abraham Jusqu'a A La Fin Du XV Siecle De J.C, trans.: Henri Sauvaire, (Paris: Libraire De La Societe Asiatique, 1876), ss. 36-37; Mustafa Fayda, Hz. Ömer Zamanında Gayr-ı Müslimler, (İstanbul: Marmara İlahiyat Fakültesi Yayınları, 1989), s. 145. 
bunu göstermektedir. Buna karşılık Müslümanların zaman içinde zayıflamasına fırsat vermemek için Hıristiyanlara yönelik birtakım uygulamalar da gerçekleştirmiştir. ${ }^{11}$ Bahsedilen uygulamalar yukarıda verilen emanda yer almamasına rağmen Şam Hıristiyanları ile yapılan başka anlaşma ve emanlarda bulunmaktadır.

Burada şunu da belirtmek gerekir ki Hz. Ömer, İslam'ın güçlenmesi için çok gayretlidir; ancak verdiği kararlarda Müslümanların desteğini almayı da ihmal etmemiş birisidir. Aynı şekilde sahip olduğu adalet anlayışı, gayri müslimlere karşı davranışlarında da görülmektedir. Nitekim Kudüs'ü gezdiği esnada Beytü'l-Lahm keşişlerinden birisi ona yaklaşıp Beytü'l-Lahm için merhametini istediğinde, onların güvende olacaklarını, Hıristiyan halkın olduğu yerlerde bunun kendileri için gerekli olduğunu belirtmiştir. Lakin Müslümanlar için bir mescit inşa etmesinin de kendileri için önemli olduğunu söylemiştir. Bunun üzerine keşiş, kiliselere dokunmadığı takdirde bunu yapabileceğini ifade etmiştir. ${ }^{12}$ Görülüyor ki $\mathrm{Hz}$ Ömer, Kudüs'e geldiğinde Müslümanların hakkını düşünürken $\mathrm{H}_{1}-$ ristiyan halkın da huzurunu göz ardı etmemiştir.

Öte taraftan yukarıda bahsi geçen anlaşma genel olarak Şam bölgesindeki diğer yerlere verilen emanlarla can, mal ve din özgürlüğü gibi konularda benzer içeriğe sahip olmasına rağmen bazı farklı maddeler de barındırmaktadır. Bu da ahidnamenin bölgenin şartlarına uygun şekilde hazırlandığına işaret etmektedir. Anlaşmada Hıristiyanlar için aşağılayıcı hiçbir maddenin bulunmadığı Müslüman olmayanlar tarafından da itiraf edilmektedir. ${ }^{13}$ Bununla birlikte bazı hususlarda tartışmalar da yok değildir. Bunlardan en dikkat çeken ve en çok tartışılan Yahudilerin şehirde Hıristiyan ahali ile birlikte yaşamasına izin verilmeyeceği maddesidir. ${ }^{14}$ Böyle bir maddenin anlaşmada yer almadığı da iddia edilmektedir. $\mathrm{O}$ halde bunu nasıl anlamak gerekmektedir?

Suriye bölgesine ait Hıristiyan kaynaklarında, İsrailoğullarının Kudüs'e girmesinin Bizans tarafından yasaklandığı, şehre girdiği

11 Corci Zeydan, İslam Uygarlıkları Tarihi, çev.: Necdet Gök, (İstanbul: İletişim Yayınları, 2012), c. 2, s. 365.

12 Guy Le Strange, Palestine Under the Moslems, (yy., University of Toronto Press, 1890), s. 300.

13 M. J. de Goeje, Memoire sur la Conquete de la Syrie, (Leiden: Brill, 1900), s. 155.

14 Yakubi, Tarihu'l Yakubi, (Beyrut: Daru'1 Kütübü'l İlmiyye, 2002), c. 2, s. 37. 
tespit edilenlerin ölümle cezalandırıldığı, bu durumun Müslümanların zafer kazanarak, Yahudilerin şehre girmesine ve burada ibadet etmesine izin vermelerine kadar devam ettiği ifade edilmektedir. ${ }^{15}$ Yahudi kaynaklarında ise Hz. Ömer'in Yahudilerin Kudüs'e yerleşmesine izin verdiği; hatta Yahudilerden 70 ailenin Tiberya' dan Kudüs'e yerleşmesine müsaade ettiği, Müslümanların Kudüs'ü fethinden hemen sonra Yahudilerin buraya geldiği ve Tapınak Tepesi'nin kapılarından birinin yakınlarına yerleşmeye başladığı belirtilmektedir. ${ }^{16} \mathrm{O}$ dönemde Kudüs'te sadece Hiristiyan halk yaşamaktadır, buna bağlı olarak patriğin halifeden bu yasağın sürmesini istemiş olması mümkündür. Lakin pratikteki uygulamalara bakıldığında Yahudiler için geçerli olan bu yasağın Müslümanların şehre yerleşmesi ile kaldırıldığı ve onların Kudüs'te oturmalarına izin verildiği görülmektedir. Böylece Yahudilerin kutsal şehir Kudüs'te tekrar varlıklarının ortaya çıkması da Müslümanların farklı dinlere olan hoşgörüsünün sonucunda gerçekleşmiştir. ${ }^{17}$ Verilen bilgiler çerçevesinde Hz. Ömer'in fethinden sonra Kudüs'te üç din mensuplarının bir arada yaşamasına imkân tanıyan yeni bir dönemin başladığı söylenebilmektedir.

Yukarıda çeşitli şekillerde söylendiği gibi Suriye bölgesi ve diğer bölgeler fethedildiğinde vergi/cizye vermek karşıllğıında Yahudi ve Hıristiyan halka ve rahiplere iyi muamelede bulunulacağını ve aleyhlerine yapılacak saldırılara karşı da korunacağını ilan eden anlaşma metinleri imzalanmıştır. Ayrıca Filistin bölgesinde bulunan Samirilerin, savaşlar esnasında Müslümanlara yaptıkları yardımlar sebebiyle cizye vergisinden muaf tutuldukları ve buralardaki diğer Yahudi-Hıristiyan halkların da Müslümanlara yardım ettiği bilinmektedir. ${ }^{18}$ Şüphesiz bunun çeşitli sebepleri bulunmaktadır; lakin Hıristiyan kaynaklarında Müslümanların Theodose komutasındaki askerlerle savaşırken yaşlılara, çocuklara ve kadınlara zarar verme-

15 Robert G. Hayland, Seeing Islam as Other Saw it, (Princeton: The Darwin Press, 1997), s. 127.

16 Moshe Gil, A History of Palestine 634-1099, (Cambridge: Cambridge University Press, 1992), ss. 70-72.

17 İsmâil Râci el-Fârûkî ve Luis Lâmia el-Fârûkî, İslâm Kültür Atlasl, çev.: Mustafa Okan Kibaroğlu ve Zerrin Kibaroğlu, (İstanbul: İnkılâp Yayınları, 1999), s. 247.

18 Şiblî Numanî, Bütün Yönleriyle Hz. Ömer ve Devlet İdaresi, çev.: Talip Yaşar Alp, (İstanbul: Çă̆ Yayınları, 1980), c. 2, s. 165. 

diklerinin ifade edilmesinde de görüleceği üzere Müslümanlar savaş zamanında dahi insan haklarına gereken hassasiyeti göstermiş, bu husus da bölge halkları tarafından kabul edilmelerinde etkili olmuştur. ${ }^{19}$ Bununla birlikte Müslümanların fetih hareketleri devam ederken bölgedeki Yahudi ve Hıristiyan halkın bu durum karşısındaki tutumuna daha yakından bakmak uygun olacaktır. Örneğin Kudüs'ün Müslümanlar tarafından fethedildiği döneme ait bir Yahudi metninde yer alan ifadelere göre; bir meleğin dindar bir Yahudiye, "Korkma Ben Yohay, Tanrı ona şükürler olsun, seni kötülüklerden (Bizans) kurtarmak için İsmail krallı̆̆ını gönderdi", dediği yazılıdır. ${ }^{20}$ Aynı şekilde Hıristiyan Bizans'a karşı Suriye'de bulunan bir Hıristiyanın da "Tanrı bizi Romalıların zulmünden kurtarmak için güneyden İsmailoğullarını gönderdi, şeklinde kaynaklarda yer alan ifadeleri bölgedeki Müslüman varlığının Yahudi ve Hıristiyan halk tarafından olumlu karşılandığını göstermektedir..$^{21}$ Onların bu tutumlarının en önemli sebebi de Müslümanlarla bir arada yaşarken dinlerini ve kültürlerini devam ettirmelerine imkân tanıyan yönetim anlayışı olmuştur.

\section{III.}

Anlaşmanın imzalanmasından sonra Hz. Ömer, Kudüs'e gelmiş ve Zeytin Dağı'na çıkmıştır. Burada halifeyi patrik Sophronius karşılamış ve pek çok insanla birlikte şehri gezerken kendisine eşlik etmiştir.22 Sophronius, İlya şehrindeki görevinin üçüncü yılında bulunmakta olup Müslümanların burayı fethedecekleri öngörüsünde bulunmuş birisidir. Bunun yanında Sophronius'un daha önceleri vaazlarında Müslümanlara karşı çeşitli söylemlerde bulunduğu ve fetihten kısa bir süre sonra da üzüntüsünden öldüğü belirtilmektedir. Bu patriğin, Hz. Ömer'in şehre girerken deve tüyünden sade bir elbise içindeki mütevazi halinden çok etkilendiği Hıristiyan kaynaklarında yer almaktadır. Öyle ki yanındaki kişiye

19 La Chronique de Jean, trans.: H. Zotenberg, (Paris: Imprimerie Nationale, 1883), s. 435.

20 Gil, A History of Palestine 634-1099, s. 70; Hayland, Seeing Islam as Other Saw it, s. 527.

21 Chronique de Michel le Syrien, trans.: J.B. Chabot, (Paris: Ernest Leroux, 1901), c. 2, ss. 412-413.

22 Moudjir ed-Dyn, Histoire De Jerusalem, ss. 40-41. 
Bu Daniel peygamberin kutsal yerde ayakta dururken söylediği harap edici mekruh şeydir, dediği kaydedilmektedir. ${ }^{23}$

Patrik Sophronius, halifeye kutsal yerleri gezdirirken Kiyamet Kilisesi'nde bulundukları esnada Hz. Ömer, namaz vakti geldiğini söyleyerek kendisine yer gösterilmesini istemiştir. Patriğin Kıyamet Kilisesi'nde kılabileceğini söylemesine rağmen halife, biraz uzaklaşarak başka bir yere abasının sermiş ve orada namazını kılmıştır. Daha sonra böyle yapmasının sebebini açıklamış ve Müslümanların burayı camiye çevireceklerini düşündüğü için kabul etmediğini söylemiştir. Nitekim Hz. Ömer'in namaz kıldığı o yere daha sonra Hz. Ömer Camii inşa edilmiştir. ${ }^{24}$

Daha sonra Hz. Ömer, patrikten kendisini Davud mescidine götürmesini istemiştir. Buraya geldiğinde ise Hz. Peygamberin İsra gecesinde anlattığı yer olduğunu söylemiş ve buraya bir mescit inşa etmiştir. Yalnız buraya geldiklerinde Sahra kayasının olduğu yerin çöplük haline çevrildiğini görmüştür. Hıristiyanlar, İsrailoğullarının daha önce gerçek haçın bulunduğu yeri çöplüğe çevirmeleri sebebiyle onlara olan düşmanlıklarından ötürü bunu yapmışlardır. ${ }^{25}$ Bunu gören halife, abasının eteğine kayanın yanındaki çöplerden alarak taşımış, Müslümanlar da onunla birlikte çalışarak orayı temizlemişlerdir. ${ }^{26}$ Ayrıca bu iş için Filistin bölgesindeki Yahudilerin ücret almadan çalıştı̆̆ı bilgisi de bulunmaktadır. ${ }^{27}$ Görüldüğü gibi Hz. Ömer, Kudüs'e geldiğinde bir mescit inşa etmiş, Yahudilerin kıblesi olan Sahra kayasını ortaya çıkarmış ve Hıristiyanların en büyük kilisesi olan Kıyamet kilisesini olduğu gibi bırakarak en ufak bir parçasına dahi dokunmamıştır. Böylece vergilerini ödemek koşuluyla her dinden insanın Kudüs'te kendi inancını devam ettirmekte özgürken ötekinin kutsallarına da saygı duyarak, barış içinde yaşamasını sağlamıştır.

Yapılan anlaşma maddelerinde bir arada yaşamaya dayalı bir anlayışı benimseyen Müslümanlar fetihten sonra da halkların refah ve huzurunu gözetmişlerdir. Bu bağlamda Hz. Ömer, fethedilen

23 Daniel, 9: 27; 11: 31; 12: 11; The Chronicle of Theophanes, trans.: Harry Turtledove, (Philadelphia: University of Pennsylvania Press, 1982), s. 39; Hayland, Seeing Islam as Other Saw it, s. 58.

24 F. Buhl, "Kudüs", IA, (İstanbul: MEB, 1986), c. 6, s. 956.

25 Moudjir ed-Dyn, Histoire De Jerusalem, ss. 41-42.

26 İbn Kesîr, el-Bidaye ve'n-Nihaye, c. 1, s. 1244.

27 Strange, Palestine Under the Moslems, s. 140. 
topraklara yerleşen Arapların ziraatla uğraşmasını yasaklamış, toprakların yerel halk tarafından işlenmesini istemiştir. Arazilerden alınan haraç/vergiler konusunda da çok titiz olan halife, Hıristiyan zimmilerin kanaatlerini sormuş ve gelen itirazlara gereken titizliği göstermiştir. Vergiler toplandıktan sonra da bunların zimmilerden haksızlıkla alınmadığına dair şahitlik ettirdikten sonra kabul etmiştir. ${ }^{28} \mathrm{~Hz}$. Ömer, Cabiye bölgesinden dönerken yaşlı ve kör bir adamin dilendiğini görmüş, ona yaklaşıp hangi dine mensup olduğunu sormuştur. Yahudi olduğunu öğrendiği kişinin bu duruma nasıl düştüğü sormuş, cizye ve yaşlılık olduğunu öğrenmiştir. Bunun üzerine Hz. Ömer o kişiye bir miktar sadaka vermiş, sonra ona beytülmâlden maaş bağlanmasını emretmiştir. Sonrasında bu kimse ve buna benzer durumda olanlardan cizye alınmasını kaldırmıştır. Böyle kimselere insaflı davranmak gerektiğini, gençliğinde cizyesini alıp ihtiyarlığında perişan halde bırakmanın doğru olmadığını belirtmiştir. Bununla birlikte zekât ayetinde ${ }^{29}$ geçen miskinlerin Ehl-i kitabın fakirleri olduğunu söyleyerek bu kimselere pay verilebileceğine işaret etmiştir. ${ }^{30}$ Sahabenin de bu görüşe karşı çıkmadığı bilinmektedir. ${ }^{31}$ Yine Hz. Ömer, Filistin bölgesinden dönerken yolda güneş altında bekleyen insanlar görmüş, bu insanlara ne olduğunu sormuştur. Cizyelerini ödemedikleri için cezalandırıldıklarını öğrendiğinde, niçin ödemediklerini sormuş ve paralarının olmadığını söyledikleri kendisine bildirildiğinde onların serbest bırakılmasını istemiş ve güçlerinin yetmediği taşıtmayın, demiştir. ${ }^{32}$

Görüldüğü gibi Hz. Ömer, siyasi kararlarında Yahudi ve Hıristiyanların haklarını gözetmiştir. Ayrıca bilindiği üzere o, Hıristiyan kölesine Müslüman olmasını tavsiye etmiş, köle bunu reddettiğinde dinde zorlama olmadığını söylemiştir. Vefatı esnasında ise zimmilerin hakları konusunda tavsiyede bulunarak şöyle demiştir: Rasulullah'm zimmilerine hakların tam olarak verilmesini can ve mallarının

28 Ebû Yûsuf, Kitabu'l-Haraç, çev.: Ali Özek, (İstanbul: Hisar Yayınevi, 1973), s. 188, 193; Numanî, Bütün Yönleriyle Hz. Ömer ve Devlet İdaresi, ss. 73-76.

29 Tevbe 9/60 (Zekâtın sarf yerleri sekizdir. Bunlar; fakirler, miskinler, zekât tahsil eden memurlar, kalpleri İslam'a ısındırılacak olanlar, köleler, esirler, borçlular, yolculardır.)

30 Ebû Yûsuf, Kitabu'l-Haraç, ss. 205-206.

31 Ebü'l-Fidâ İmâdüddin İsmâil b. Şihâbiddîn Ömer İbn Kesîr, Hadislerle Kur'an-ı Kerim Tefsiri, çev.: Bekir Karlığa ve Bedreddin Çetiner, (İstanbul: Çağrı Yayınları, 2005), c. 7, s. 3516.

32 Ebû Yûsuf, Kitabu'l-Haraç, s. 204. 
emniyeti uğrunda gerekirse savaşılmasın, takatlerinin üstünde yükler yüklenmemesini tavsiye ederim. ${ }^{33}$

IV.

Müslümanların fethedilen bölgelerdeki Yahudi ve Hıristiyanlara karşı tutumu onların İslam'a davet edilmesi, kabul etmedikleri takdirde cizye ödeyerek kendi inançlarını devam ettirmelerine izin verilmesi şeklinde olmuştur. Ayrıca herhangi bir baskıya uğramaları da reddedilmiştir. Bunun sonucu olarak da farklı dinlerin mensuplarının İslam toplumu içinde asimile edilmeleri engellenmiştir. Hz. Peygamber'in uygulamaları bu yönde olup Hz. Ömer döneminde bu anlayış devam ettirilmiştir. Bununla birlikte Hz. Ömer döneminde sosyal hayattaki birtakım gelişmelere paralel olarak çeşitli düzenlemeler yapılmıştır. Buna bağlı olarak Yahudi ve Hıristiyanlarla gerçekleşen ilişkilerdeki bazı hususlarda çeşitli tartışmalar bulunmaktadır.

Bunlardan biri ayette zekât verilecek kimseler arasında sayılan müellefe-i kulup/kalpleri İslam'a 1sındırılacak kimselere -ki Hz. Peygamber döneminde buna uygun kişilere sarf edilmiştir- Hz. Ömer'in zekâttan pay vermeyi durdurmasıdır. Bu hadise Hz. Ebubekir döneminde gerçekleşmiştir. Şöyle ki Necid bölgesinden Uyeyne İbn Hısın ile Akra İbn Habis adlı kişiler kendi yakınlarındaki bir araziyi istemişlerdir. Bunu kabul eden Hz. Ebubekir şahit olarak imzalamak üzere o kişileri Hz. Ömer'e göndermiştir. Hz. Ömer, Hz. Peygamber sizleri İslam'a çağırdığında o gün azınlıktaydı; ancak Allah İslam'ı zenginleştirmiştir, diyerek kararı onaylamamıştır. Bu kişiler itiraz ederek tekrar Hz. Ebubekir'e gitmişler; lakin o da Hz. Ömer'i tasdik etmiştir. Böylece müellefe-i kuluba verilen zekâtın Müslümanların azınlıkta olduğu dönemde uygulandığı belirtilmiş ve sahabelerden de buna karşı çıkan olmamıştır. Bununla beraber müellefe-i kuluba zekâttan pay verilmesi hususu ihtilaflıdır. Bir k1sım kimseler (Hanefi-Maliki) Hz. Peygamber'den sonra müellefe-i kuluba pay verilmeyeceği görüşünde iken diğer bir grup verileceğini söylemektedir. ${ }^{34}$ Müellefe-i kulup kimseler içine Müslümanlara zarar vermesinden çekinilen kişiler de dâhil edilerek onlara da zekâttan pay verilmiştir. Buna göre Hz. Ömer, artık onların zararın-

\footnotetext{
33 Ebû Yûsuf, Kitabu'l-Haraç, s. 203.

34 İbn Kesîr, Hadislerle Kur'an-ı Kerim Tefsiri, c. 7, s. 3518, 3523.
} 
dan çekinilmediğini işaret etmiştir. Bu durumda Hz. Ömer'in zekâttan pay vermemesi, bahsedilen kimselerin ayette yer alan vasiflarını kaybettikleri ve o dönemde müellefe-i kulup kabul edilecek kimselerin bulunmadığ

Diğer bir konu Hz. Peygamber döneminde kıyafetle ilgili bir düzenleme bulunmamakla birlikte Hz. Ömer'in zimmilerin kıyafetlerinin Müslümanlara benzemesine müsaade etmemesidir. Hz. Ömer, valilere yazdığı mektuplarda Hıristiyanların zünnar/kemer takmalarını, senede bir gün bayram günleri hariç Müslümanlar arasında alay halinde haç çıkarmamalarını, ezan öncesinde çan çalmamalarını, onların mezarlıklarının Müslüman mezarlıkları yanında olmamasını emretmiştir. ${ }^{36}$ Bunun sebebi ise Müslümanlar ile zimmilerin ayırt edilmesi olup onları belli kıyafetlere mecbur etmek değildir. Ayrıca Hz. Ömer'in kıyafetlerle ilgili uygulaması onların İslam toplumu içinde varlıklarını ve kültürlerini korumasını sağlamıştır. Çanların ise çalınmaması değil ezan saatinden önce olmaması istenmiştir. Hz. Ömer'in valilere yazdığı mektuplarında zimmilere güçleri nispetinde cizye konulmasını, Müslümanların onlara haksızlık etmemelerini, zarar vermelerinin önlenmesini ve onlara verilen sözlerin tam olarak yerine getirilmesini emrettiği de bilinmektedir. ${ }^{37}$ Hatta sahabenin ileri gelenlerinden biri dahi olsa bir Hıristiyana haksızlık yapıldığını gördüğünde ona müdahale etmiştir. Amr bin As hakkında böyle bir şikâyet olduğunda ondan Hıristiyanın hakkını almıştır. Aynı şekilde Suriye bölgesindeki bir çiftçi, ordunun tarlasındaki ürününü çiğnediğine dair şikâyetini ilettiğinde de o kişinin zararını karşılamıştır. Bu da onun zimmilerin haklarına ne kadar önem verdiğini göstermektedir. Bununla beraber halifenin bahsi geçen kararı yanında zimmilerin devlet işlerinde çalışmasına engel olmadığı da bilinmektedir. Öyle ki Hz. Ömer, bir memlekette bulunan vergi defterlerinin lisanlarını olduğu gibi bırakmıştır. Buna göre Suriye kayıtları Latince, Irak-İran kayıtları Farsça ve Mısır'dakiler ise Kıpti dilinde tutulmaya devam etmiş,

35 Saffet Köse, “Hz. Ömer'in Bazı Uygulamaları Bağlamında Ahkâmın Değişmesi Tartışmalarına Bir Bakış", İslam Hukuku Araştırmaları Dergisi, 2006, sayı 7, s. 19, 22,23 .

36 Ebû Yûsuf, Kitabu'l-Haraç, s. 228; Moudjir ed-Dyn, Histoire De Jerusalem, s. 39; Numanî, Bütün Yönleriyle Hz. Ömer ve Devlet İdaresi, s. 222, 225.

37 Ebû Yûsuf, Kitabu'l-Haraç, ss. 207-228. 
arazi vergisinde çalışan İranlı, Yunan ve Kıptilerin görevleri değiştirilmemiştir. Görüldüğü gibi Hz. Ömer'in Yahudi ve Hıristiyanlara yönelik birtakım uygulamaları onlara olan düşmanlığı sebebiyle olmayıp siyasi kararlarının neticesidir. ${ }^{38}$

Tartışmalı bir diğer husus Hicaz topraklarında yaşayan Yahudi ve Hıristiyan halkı bulundukları yerden çıkarmasıdır. Hz. Ömer, Hz. Peygamber ile anlaşmaları bulunan Hayber Yahudilerini ${ }^{39}$ ve yine Hz. Peygamber ile anlaşmaları olan Necran Hıristiyanlarını ${ }^{40}$ hilafetinin ilk dönemlerinde herhangi bir müdahalede bulunmamasına rağmen daha sonra İslam devleti sınırları içinde başka yerlere naklettirmiştir. Bunu Hz. Peygamberin bir hadisine ${ }^{41}$ dayanarak yaptığına dair görüşler olduğu gibi siyasi nedenlerle gerçekleştirdiği hakkında rivayetler de bulunmaktadır. Hz. Ömer, sahabeyi toplayarak Yahudilerin Abdullah bin Ömer'e ve ensardan birine yaptıkları saldırılar sebebiyle Suriye taraflarına iskân edileceğini bildirmiş ve mahsullerinin kıymetini kendilerine ödemiştir. Necranlılar ise askeri amaçlarla at ve silah tedarik etmeleri sebebiyle Müslümanlara zarar verecekleri endişesiyle yerlerinden çıkarılarak

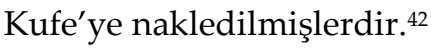

Beni Tağlib Hıristiyanları ile yapılan anlaşmada yer alan çocuklarını vaftiz etmeyecekleri maddesi hakkında da çeşitli tartışmalar bulunmaktadır. Şöyle ki Beni Tağlib Hıristiyanları Arap bir kavim olup cizye vermek istememişler ve Rum diyarına kaçmışlardır. Bunun üzerine Hz. Ömer, onlarla iki kat zekâtla yükümlü tutulmaları

Belâzurî, Fütûhu'l-Büldân, s. 277; Zeydan, İslam Uygarlıkları Tarihi, c. 2, s. 360, 370; Fayda, Hz. Ömer Zamanında Gayr-ı Müslimler, s. 176; Numanî, Bütün Yönleriyle Hz. Ömer ve Devlet İdaresi, c. 2, s. 67, 68, 214. Süleyman bin el-Eş'as bin İshâk es-Sicistânî Ebû Dâvûd, es-Sünen, “Kitabü'l Harac-İmare ve Fey"', 24, (Beyrut: Al-Resalah Al-A'lamiah, 2012). Ebû Yûsuf, Kitabu'l-Haraç, s. 126 (Necran halkı ile Rasulullah'ın yazdığı ahidname şöyledir: onların malları, canları, arazileri, meskenleri ve dinleri Allah'ın ve Rasulünün zimmetindedir. Papazları, din adamları ve kâhinlerinden hiçbiri değiştirilemez. Haksız yere ahidlerini bozmadıkları sürece Allah'ın takdiri gelinceye kadar bu namede yazılan hak ve vecibeler Allah ve Rasulünün zimmet ve riayetindedir.)

41 Ebû Dâvûd, "Kitabü’l Harac-İmare ve Fey", 28 (Arap yarımadasından Yahudi ve Hıristiyanları çıkaracağım. Orada Müslümanlardan başkasını bırakmayacağım).

42 Ebû Yûsuf, Kitabu'l-Haraç, s. 128; Taberî, Milletler ve Hükümdarlar Tarihi, çev.: Zâkir Kadirî Ugan ve Ahmet Temir, (İstanbul: MEB Yayınları, 1992), c. 5, ss. 619620; Fayda, Hz. Ömer Zamaninda Gayr-ı Müslimler, ss. 183-188. 
ve çocuklarını vaftiz etmemeleri şartlarıyla anlaşmıştır. ${ }^{43}$ Diğer kavimlerle yapılan anlaşmalarda cizye verdikleri takdirde dinlerini özgürce yaşama hakkı tanınırken Beni Tağlib Hıristiyanları ile yapılan anlaşmada böyle bir maddenin bulunması ilginçtir. Bu şartın babası İslam'ı seçmiş ve vefat etmiş kimselerin çocukları için geçerli olduğu söylenmiştir. ${ }^{44}$ Her ne kadar Beni Tağlib Hıristiyanları hakkındaki şartın Hz. Ömer dönemine ait olduğu ifade edilse de Hz. Peygamber'in bunlarla yaptığı anlaşmada da bahsedilen maddenin yer aldığı görülmektedir. Hz. Peygamber'in Yemen ve Uman bölgelerindeki Hıristiyanlara böyle bir şart ileri sürmemesine rağmen Beni Tağlib Hıristiyanlarının çocuklarını vaftiz etmeyeceklerini neden belirttiğinin sebebi ise bilinmemektedir. ${ }^{45}$

Bir başka konu ise Hz. Peygamber döneminde haraçla ilgili herhangi bir uygulamanın olmamasına karşın Hz. Ömer'in fethedilen toprakları ganimet olarak dağıtmayıp orada yaşayan insanların ellerinde bırakarak onları haraç/toprak vergisi ile yükümlü tutmasıdır. Irak ve Suriye bölgesindeki komutanlar, topraklar konusunda halifeye görüşünü sormuşlar, o da toprakların yerli halkın elinde bırakılıp vergi alınmasını istemiştir. Lakin bazı sahabeler ganimet ayetine göre savaşılarak alınan yerlerin dağıtılması gerektiğini iddia etmişlerdir. Hz. Ömer, eğer size bölüştürürsem sizden sonra gelecek olanlara bir şey kalmaz, diyerek bunu kabul etmemiştir. ${ }^{46} \mathrm{~Hz}$. Ömer'in bu tavrını nasıl anlamak gerektiği konusunda öncelikle Hz. Peygamber dönemi uygulamalarına bakıldığında Hayber'in ganimet kabul edilerek savaşan sahabilere dağıtıldığı, daha sonra ise Yahudilerin teklifi üzerine ürünün yarısı karşılığında yerli halkın elinde bırakıldığı bilgisiyle karşılaşılmaktadır. Buna göre Hz. Peygamber' in yaptığı gibi dağıtılabileceği veya Hz. Ömer'in yaptığı gibi haraç alınabileceğine dair görüş oluşmuştur. Ayrıca fethedilen topraklar konusunda kesin bir hüküm olsaydı sahabilerden hiç kimse bunu kabul etmezdi. Oysa Hz. Ali ve Hz. Osman gibi sahabeler Hz. Ömer'in bu konudaki görüşünü tasdik etmişlerdir. ${ }^{47}$ Görüldüğü gibi Hz. Ömer döneminde fethedilen topraklar savaşanlar arasında dağıtılmamış ve insanların esir ya da köle olmadan kendi

\footnotetext{
43 Belâzurî, Fütûhu'l-Büldân, ss. 260-262.

44 Fayda, Hz. Ömer Zamanında Gayr-ı Müslimler, s. 155.

45 Muhammed Hamidullah, İslâm Peygamberi, çev.: Mehmet Yazgan, (İstanbul: Beyan Yayınlar1, 2004), ss. 331-332.

46 Ebû Yûsuf, Kitabu'l-Haraç, ss. 57-59.

47 Fayda, Hz. Ömer Zamanında Gayr-ı Müslimler, s. 73, 77, 78.
} 
topraklarında vergilerini vermek suretiyle özgürce yaşamalarına müsaade edilmiştir.

\section{Kaynakça}

Belâzurî. Fütûhu'l-Büldân, çev.: Mustafa Fayda, (Ankara: Kültür ve Turizm Bakanlığı Yayınları, 1987).

Buhl, F. "Kudüs", IA (İstanbul: MEB, 1986) c. 6.

Chronique de Michel le Syrien, trans.: J.B. Chabot, (Paris: Ernest Leroux, 1901). Ebû Dâvûd, Süleyman bin el-Eş'as bin İshâk es-Sicistânî. es-Sünen, (Beyrut: Al-Resalah Al-A'lamiah, 2012).

Ebû Yûsuf. Kitabu'l-Haraç, çev.: Ali Özek ( çev.), (İstanbul: Hisar Yayınevi, 1973).

el-Fârûkî, İsmâil Râci ve el-Fârûkî, Luis Lâmia. İslâm Kültür Atlası, çev.: Mustafa Okan Kibaroğlu ve Zerrin Kibaroğlu, (İstanbul: İnkılâp Yayınları, 1999).

Fayda, Mustafa. Hz. Ömer Zamanında Gayr-ı Müslimler, (İstanbul: Marmara İlahiyat Fakültesi Yayınları, 1989).

Gil, Moshe. A History of Palestine 634-1099, (Cambridge: Cambridge University Press, 1992).

Goeje, M. J. De. Memoire sur la Conquete de la Syrie, (Leiden: Brill, 1900).

Hamidullah, Muhammed. İslâm Peygamberi, çev.: Mehmet Yazgan, (İstanbul: Beyan Yayınları, 2004).

Hayland, Robert G. Seeing Islam as Other Saw it, (Princeton: The Darwin Press, 1997).

Hitti, Philip Khuri. Siyasal ve Kültürel İslam Tarihi, çev.: Salih Tuğ, (İstanbul: IFAV, 2011).

İbn Kesîr, Ebü'l-Fidâ İmâdüddin İsmâil b. Şihâbiddîn Ömer. el-Bidaye ve'nNihaye, (Amman: Beytü'l Efkarü'l Devliyye, 2004).

Hadislerle Kur'an-ı Kerim Tefsiri, Bekir Karlığa ve Bedreddin Çetiner (çev.), 16 Cilt, İstanbul: Çağrı Yayınları, 2005.

İbnü'1 Esîr; el-Kamil Fi't Tarih Tercümesi İslâm Tarihi, çev.: M. Beşir Eryarsoy, (İstanbul: Bahar Yayınları, 1985).

Köse, Saffet. “Hz. Ömer' in Bazı Uygulamaları Bağlamında Ahkâmın Değişmesi Tartışmalarına Bir Bakış", İslam Hukuku Araştırmaları Dergisi, 2006, say1 7, ss. $13-50$.

Köylü, Mustafa. “Dinsel Dışlayıcılık”, İslam ve Öteki, ed.: Cafer Sadık Yaran, (İstanbul: Kaknüs Yayınları, 2001).

La Chronique de Jean, trans.: H. Zotenberg, (Paris: İmprimerie Nationale, 1883).

Moudjir ed-Dyn. Histoire De Jerusalem Et D'Hebron Depuis Abraham Jusqu'a A La Fin Du XV Siecle De J.C, trans.: Henri Sauvaire, (Paris: Libraire De La Societe Asiatique, 1876).

Strange, Guy Le. Palestine Under the Moslems, (yy., University of Toronto Press, 1890). 
Bir Arada Yaşama Bağlamında Hz. Ömer Döneminde Kudüs

Şiblî Numanî. Bütün Yönleriyle Hz. Ömer ve Devlet İdaresi, çev.: Talip Yaşar Alp, (İstanbul: Çă̆ Yayınları, 1980).

Taberî. Milletler ve Hükümdarlar Tarihi, çev.: Zâkir Kadirî Ugan ve Ahmet Temir, (İstanbul: MEB Yayınları, 1992).

The Chronicle of Theophanes, trans.: Harry Turtledove, (Philadelphia: University of Pennsylvania Press, 1982).

Yakubi. Tarihu'l-Yakubi, (Beyrut: Daru'l Kütübü'1 İlmiyye, 2002).

Yaran, Cafer Sadık. "Dinsel Kapsayıcılık”, İslam ve Öteki, ed.: Cafer Sadık Yaran, (İstanbul: Kaknüs Yayınları, 2001).

Zeydan, Corci. İslam Uygarlıkları Tarihi, çev.: Necdet Gök, (İstanbul: İletişim Yayınlar1, 2012). 